\title{
Perspectives on Leadership from Female Engineering Deans
}

"Being a female leader in a male dominated profession is challenging...not because of overt sexism, though that can exist, but because of expectations that the behavior of a "leader" should be "male". Women engineering leaders should not feel pressure to emulate men...they need to be comfortable with their own "feminine" style of leadership that can be just as firm, visionary and effective as a man's style...but it is different."

- Pam Eibeck, former Dean of Engineering, Texas Tech, currently President, University of the Pacific

\section{Introduction}

Despite tremendous gains over the past 30 years, women are still severely underrepresented in engineering and engineering education. In 2009 , only $17.8 \%$ of the more than 74,000 engineering bachelor's degrees awarded in the United States went to women, down from $21.2 \%$ in 1999 . Women are currently $12.7 \%$ of all engineering faculty, and only $7.7 \%$ of full professors in engineering schools. (Gibbons 2010) The advancement of women into leadership roles in engineering education has the potential to make engineering as a career more attractive to young women, and to encourage women currently pursuing careers in engineering education to aspire to leadership positions themselves.

According to the American Society for Engineering Education (ASEE), 69 women have served as dean of engineering at one of the almost four hundred engineering or technology colleges in the United States and Canada that are institutional members of ASEE, and 38 women held that title in spring of 2010. Of those women, eleven served as interim or acting dean, and about a dozen have led small programs consisting of a single department. Six women have been dean at bachelor's degree granting institutions, one at a specialized engineering school, 28 at masters level institutions, three at doctoral universities, 12 at research universities with a high level of research, and 19 at institutions classified as "research universities-very high research" by the Carnegie Foundation, including four Ivy League universities. Seven of the 50 largest engineering schools (in terms of bachelor's degrees awarded) are or have been lead by women, and one of these institutions (Purdue) currently has its second female dean. Demographic information is not readily available, but the majority of these women are white. At least half a dozen were born outside the United States, one is Asian-American, at least one is Hispanic, and three are African-American.

These statistics are a big change from 1984, when the first female dean of engineering in the United States, Eleanor Baum, was appointed dean at Pratt Institute. Dean Baum moved to Cooper Union in 1987, and served as dean there until her retirement this year. The next female dean was not appointed until 1995, and then a few women were appointed each year for the next ten years. The majority of female deans have assumed that role since the turn of the century, with several women appointed dean each year since 2005, and nine appointed in 2009. Of the 31 former deans, half have gone on to other academic leadership roles including provost, vicepresident for research, chancellor, and president.

Why should we care about the perspectives of female deans of engineering? A dean is in some ways a classic middle manager, located between the faculty and department heads on the one hand and the provost and president of the university on the other, responsible for mediating between the two. Due to the shared governance model of universities, faculty members control 
the curriculum, direct their own research agendas, and have significant input into university policies while the central administration is responsible for overall coordination. However, in many ways deans have a high degree of autonomy in leading their colleges, developing a strategic vision, setting priorities, raising money, hiring faculty, allocating resources, and ensuring educational quality. Thus, the individual who occupies the dean's office plays an important role in defining the work environment and establishing the climate for faculty and students. A deanship is also a common stepping stone for higher academic leadership positions.

How do these women see their role as dean? What career paths prepared them for the position? What perspectives do they bring to the deanship? What can we learn from them about engineering and about leadership? This article seeks to address these questions through the eyes and words of the deans themselves.

\section{Methodology}

The author interviewed 21 female deans of engineering, about $30 \%$ of the total and $36 \%$ of those who have held the position on a permanent basis, for profiles published annually in the Society of Women Engineers Magazine since 2002. Those interviewed were not selected at random. At first, there were few women deans to choose from, but as the project continued two or three women were selected each year to represent different types of institutions (public vs. private, large vs. small), engineering disciplines, and geographic locations. In a structured interview, each dean was asked to describe her role and accomplishments as dean, her career paths, and her perspective on the impact of gender on her leadership style. The interviews provide insights into how these particular women at this point in time see themselves as leaders and how they are leading their institutions in creating engineers for the twenty-first century.

\section{What Do Deans Do?}

The role of dean in American universities has evolved as the institutions themselves have evolved. Today, the responsibilities of deans vary depending on the size and mission of the university and the college or school, but in all cases include responsibilities for budget and personnel management. Deans are responsible for recruiting faculty, providing faculty with the resources they need to succeed, and building and maintaining a good work environment. They also represent their colleges within the university and to outside stakeholders. Deans are responsible for academic quality within their unit, and fundraising is becoming an increasingly important part of the dean's job. (Wolverton, Gmelch et al. 2001)

A national study of academic deans identified six areas of a dean's responsibility: external and political relations, personal scholarship, leadership, resource management, internal productivity, and academic personnel management (Montez, Wolverton et al. 2002). Another study of academic deans in research and doctoral institutions identified relationship building as a key component of successful leadership in higher education, and examined disciplinary differences among deans. The author found that deans from applied disciplines such as engineering that exhibit a high degree of agreement about research problems, methods, and criteria tend to take a more bureaucratic and less social approach to leadership. That is, their leadership style tends to be more hierarchical and less collegial. (Del Favero 2005)

While deans are often viewed as administrators and managers responsible for budgets, policies, rules, and deadlines (and those are certainly important parts of their role), the female 
engineering deans interviewed emphasize that a big part of their job is working with people. Unlike a manager in a corporation, an academic dean cannot merely mandate changes in priorities or direction. Faculty members are very independent, and many decisions at a university are made collegially, through committees that provide opportunities for faculty input. Thus deans must work with their faculty to establish and achieve common goals. Linda Abriola, dean of engineering at Tufts, observed that "Everything I do is through other people."

Other deans also focus on the people aspects when describing their job. Denice Denton, former dean of engineering at the University of Washington, when describing her accomplishments as dean, stated: "I have worked very hard to make the college peoplecentered." In addition to her role as "CEO of an academic unit" (Denton), a dean is also "a facilitator ... bringing together people and ideas" (Esin Gulari, Clemson). Deans serve as a "catalyst to develop vision, goals and momentum" (Cheryl Schrader, Boise State) and then must be "able to excite faculty, staff, and students" (Eibeck) about that vision and "keep everyone moving on a path to achieve the vision and mission of the school." (Susan Blanchard, Florida Gulf Coast)

Colleges have many stakeholders, including most obviously faculty and students, but also parents, alumni and other donors, research funding agencies, accrediting authorities, local industries and economic development agencies. When she became dean, Pam Eibeck realized that her college has "many more constituents than you could ever dream!" A dean must be an "advocate for the college" (Schrader) who "helps faculty and students reach their goals" (Zorica Pantic-Tanner, former dean of engineering, University of Texas, San Antonio, currently president of Wentworth Institute of Technology), "makes sure students are well cared for" (Deirdre Meldrum, Arizona State), and "makes it easier for department chairs, faculty, staff, and students to do their work and learning" (Blanchard).

Deans "get to wear a lot of different hats". (Abriola) In addition to their responsibilities to their college and university, deans sometimes have the opportunity to take a leadership role on national issues related to engineering. Ilene Busch-Vishniac, former dean at Johns Hopkins, currently provost at McMaster University, enjoyed using her position as dean of a prestigious institution to "... press forward on some important items nationally. In particular, I have become active and vocal on issues of diversity in engineering and in improvements of undergraduate education in engineering."

The women deans interviewed acknowledge the multiple responsibilities of their positions, from vision setting to budget balancing, but when asked to describe what deans do, they focus on people. Students, faculty, staff, alumnae, donors, legislators, employers, all require some kind of attention from deans. The ability to balance - or juggle - all of the demands on their time and attention is key to success as a dean.

\section{Career Paths of Deans}

Many paths lead to the deanship. Deans may begin their administrative careers as department chair or associate dean, or through a number of different routes. In the mid-1990s, two-thirds of male deans but only slightly more than half of female deans studied had prior experience as a department head (Wolverton and Gonzales 2000). Few deans receive any formal training for their role. Deans report that experience in past administrative positions and relationships with faculty leaders were the most valuable preparation for becoming a dean, regardless of their disciplinary background (Del Favero 2006). 
The female deans interviewed for this project have taken a variety of routes to their current positions. Most of the women appointed deans of engineering in the 1980s and 1990s had not previously served as a department head or chair, but many of the more recent appointees did have that experience. Linda Lucas, dean at the University of Alabama, Birmingham, is glad she was a chair first. "When I became chair, I was glad I had been through the research grant process so that I knew what faculty go through. Being chair helped prepare me for the dean position...going through the academic career ladder gives me more confidence and credibility." Esin Gulari (Clemson) notes that "Experience as a department chair is so valuable. The department is the critical unit, deciding about hiring, promotion, workload, curriculum, accreditation...I would not want to be dean without that experience."

Nevertheless, deans come to their position with many different types of preparation, including experience as National Science Foundation program officers, directors of major research centers, chairs of important university committees, and officers in professional societies. For Kristina Johnson, former dean at Duke and currently Under Secretary for Energy at the U.S. Department of Energy, "becoming director of an NSF funded Engineering Research Center led to connections across universities and got me thinking broader." Sallie Ann Keller came to Rice University as dean of engineering after leading the statistical sciences group at Los Alamos National Laboratory. Candis Claiborn at Washington State University followed a mentor into an associate dean position and then was asked to become interim dean before being named to the post permanently.

Most of the women interviewed did not set out to become a dean, but took advantage of career opportunities as they arose. Keller explained:

“...I can honestly say I did not spend much time planning any of it. However, what I did do was embrace new and interesting challenges, whether it was the opportunity to go to the National Science Foundation and direct a research program, go to Los Alamos National Laboratory and build a world-class statistical sciences group, or come to Rice and lead a top-ranked school of engineering, I never questioned my decisions and I never looked back."

Pam Eibeck thinks she may have been the only assistant professor who actually wanted to become a dean. Early in her career she was "fascinated by people who had a big, broad vision of where the university fit into the large society, what changes were going on in the legislature, the economy, with students. ... Many researchers focus on narrow problems, but I like to think broadly, so administrative jobs were interesting...I can make a difference and shape an exciting future for the college..."

Linda Lucas and Janie Fouke did not start out in engineering at all, but taught math and science at the pre-college level before returning to school for their engineering degrees. Susan Blanchard also began her engineering career at a later age after having two children. She notes "I was a late bloomer in terms of my career". All three are biomedical engineers. Fouke originally planned on attending medical school, but got married, had three children, and started teaching instead. She says "I burned out after a couple of years of teaching, so decided to go back to school...[I] had to be very focused to juggle family and school, dragged my kids back with me at night so I could do my lab work." Diane Dorland (Rowan University) worked in industry and started a family before returning to school for a $\mathrm{PhD}$ and academic career.

The varied career paths of these women demonstrate that many roads can lead to the dean's office. A few of these women took a direct academic route: bachelor's degree, master's degree, doctorate, assistant professor, associate professor, professor, department head, dean. 
Others tried working in industry or teaching at the pre-college level before completing their doctorate and entering the academic career path. Some had children early on while others delayed families until after tenure or chose not to have children. Some gained administrative experience through major research centers, others through professional societies or government agencies. Their experiences demonstrate that there is no formula for becoming a dean, and many routes can ultimately lead to a deanship.

\section{Gender and Leadership}

Women in leadership roles or aspiring to leadership roles, especially in predominantly male fields, encounter a double bind. If they are perceived as "too feminine", they may not be viewed as effective leaders. That is, if a woman is perceived as kind, helpful, sympathetic, and nurturing, characteristics stereotypically attributed to women, people may not see her as having traits considered necessary for leadership, such as independence, decisiveness, and confidence. On the other hand, if a woman is viewed as assertive, forceful, risk taking, and dominant, characteristics commonly associated with leadership, she may be criticized for being unfeminine. (Eagly and Karau 2002, Eagly 2007) The quote from Pam Eibeck at the beginning of this article illustrates this challenge faced by female deans of engineering. In interviews with the deans, they gave different perspectives on the influence of gender on their leadership style.

Some of the women deans do not perceive their gender as having a significant impact on their leadership. Ilene Bush-Vishniac (Johns Hopkins) observed "My experience is that every individual approaches leadership in a manner that makes them most comfortable. This is true for men and women alike, and I can't honestly say that my style has been greatly influenced by my gender." Sallie Ann Keller (Rice) sees more influence from her disciplinary background:

"I honestly don't know [how being a woman influences my leadership style] and don't really spend much time thinking about this. I think the fact that I am a statistician has an interesting influence on my leadership style. I am driven by data and fact, logic and fairness."

Janie Fouke (Michigan State) noted "...some of the things characteristic of me, I'm not sure whether they are gender or Janie..."

Other deans clearly believe that women bring a different perspective to leadership roles. Denice Denton (University of Washington) asserted "I believe that women leaders are more interested in building consensus and buy-in. I also believe that they are more interested in transparency." Zulma Toro-Ramos (Wichita State) believes that "Even when you don't want to admit it and try to leave gender aside, what happens is you are more compassionate, you care more about people; even when you don't want to admit it, it is part of your style." Dierdre Meldrum (Arizona State) observed "Initially, I had to be more forceful. ...I've been told that my groups and teams are more collaborative because I am a woman...I don't have any data on that, but it feels right."

Recent studies of leadership identify a transformational leadership style, a model based on empowering, encouraging, and mentoring subordinates, in contrast to a more traditional style of leadership based on rewards and punishment. Research indicates that women may be more likely to employ this transformational style of leadership than men. (Eagly 2007) A transformational style of leadership may be particularly appropriate in higher education, where faculty expect to have a high degree of input into organizational decisions. Overall, the women deans interviewed frequently used words like "collaborative", "good communicator", 
"inclusive", "nurturing", and "team building", terms that align well with a transformational approach to leadership, when asked to describe their leadership style.

\section{Concluding Thoughts}

As leaders in what is still a predominantly male environment, female deans of engineering must continuously navigate between expectations of colleagues about what constitutes a good leader and what is appropriate behavior for a woman. While some research indicates that engineering deans tend to be more bureaucratic and hierarchical than deans in the humanities and social sciences (Del Favero 2005), the women deans interviewed tended to focus on the relational aspects of their job and the importance of people skills in accomplishing their goals. Their collaborative approach may be particularly effective in the decentralized environment of higher education. Female deans are still a small minority in engineering education, but as the presence of women in leadership roles increases it will be interesting to observe their impact on the profession.

\section{References}

Del Favero, M. (2005). "The Social Dimension of Academic Discipline as a Discriminator of Academic Deans' Administrative Behavior." The Review of Higher Education 29(1): 6996.

Del Favero, M. (2006). "Disciplinary variation in preparation for the academic dean role." Higher Education Research \& Development 25(3): 277-292.

Eagly, A., and S. Karau (2002). "Role Congruity Theory of Prejudice Toward Female Leaders." Psychological Review 109(3): 575-598.

Eagly, A. (2007). "Female Leadership Advantage and Disadvantage: Resolving the Contradictions." Psychology of Women Quarterly 31:1-12.

Gibbons, M. T. (2010) "Engineering by the Numbers." American Society for Engineering Education. Washington, DC. http://www.asee.org/publications/profiles/upload/2009ProfileEngOverview.pdf

Montez, J. M., M. Wolverton, et al. (2002). "The Roles and Challenges of Deans." The Review of Higher Education 26(2): 241-266.

Wolverton, M., W. H. Gmelch, et al. (2001). The Changing Nature of the Academic Deanship. ASHE-ERIC Higher Education Report. A. Kezar. Washington. 28.

Wolverton, M. and M. J. Gonzales (2000). Career Paths of Academic Deans. American Educational Research Association. New Orleans, LA.

\section{Deans interviewed}

Eleanor Baum, Pratt Institute 1984-1987, Cooper Union 1987-2010

Denice Denton, University of Washington 1996-2005

Ilene Bush-Vishniac, Johns Hopkins 1998-2003

Janie Fouke, Michigan State 1999-2005

Kristina Johnson, Duke 1999-2007 
Diane Dorland, Rowan University 2000-present

Linda Lucas, University of Alabama, Birmingham 2001-present

Zorica Pantic-Tanner, University of Texas, San Antonio 2001-2005

Zulma Toro-Ramos, University of New Haven 2001-1005, Wichita State 2005-present

Linda Katehi, Purdue 2002-2006

Belle Wei, San Jose State, 2002-present

Linda Abriola, Tufts 2003-present

Cheryl Schrader, Boise State 2003-present

Pam Eibeck, Texas Tech 2004-2009

Susan Blanchard, Florida Gulf Coast 2005-present

Sallie Ann Kelly, Rice 2005-present

Cherrice Traver, Union College 2005-present

Sandra Woods, Colorado State 2005-present

Candis Claiborn, Washington State 2006-present

Esin Gulari, Clemson 2006-present 